African Crop Science Journal by African Crop Science Society is licensed under a Creative Commons Attribution 3.0 Uganda License. Based on a work at www.ajol.info/ and www.bioline.org.br/cs DOI: http://dx.doi.org/10.4314/acsj.v25i4.1

\title{
SHOOT WATER CONTENT AND REFERENCE EVAPOTRANSPIRATION FOR DETERMINATION OF CROP EVAPOTRANSPIRATION
}

\author{
J.O. OMONDI, N.W. MUNGAI ${ }^{1}$, J.P. OUMA ${ }^{1}$ and F.P. BAIJUKYA ${ }^{2}$ \\ French Associates Institute for Agriculture and Biotechnology of Drylands, Ben Gurion University of the \\ Negev, 84990, Beer Sheba - Israel \\ ${ }^{1}$ Crops, Horticulture and Soils Department, Egerton University, P. O. Box 536-20115 Egerton, Kenya \\ ${ }^{2}$ International Institute of Tropical Agriculture (IITA), Dar-es-salaam, Tanzania \\ Corresponding author: okoth05@gmail.com
}

(Received 27 May, 2016; accepted 26 September, 2017)

\begin{abstract}
Determination of water requirement for crops in resource limited areas is challenging, yet worsened by the common assumption that all crop varieties within a species have similar water requirements. The objective of the study was to indirectly determine crop evapotranspiration of soybean varieties, using reference evapotranspiration and shoot water content under tillage and no tillage cultivation. The treatments were no tillage and conventional tillage as main plots, and soybean varieties Nyala, SB19, and SB20 as sub-plots, replicated three times. Crop evapotranspiration $\left(\mathrm{ET}_{\mathrm{C}}\right)$ and crop coefficient $\left(\mathrm{K}_{\mathrm{C}}\right)$ were different among varieties, and increased during growth period. SB20 had the highest $\mathrm{K}_{\mathrm{C}}(0.8437$ at 87 days after planting - DAP); followed by SB19 $(0.7888$ at 70 DAP), and Nyala (0.7026 at 66 DAP). Conversely,water use efficiency (WUE) was 0.58 in SB19, 0.52 in Nyala, and 0.47 in SB20. Validation of the calculated $\mathrm{ET}_{\mathrm{C}}$ using a crop production function showed a correlation of $\mathrm{r}=$ 0.97 between the observed and predicted yields of the three varieties. Furthermore, the normalised root mean square error (NRMSE) and the index of agreement (d) were 0.14 and 0.87 , respectively indicating accurate fit. Calculated crop coefficient strongly correlated with observed shoot water content of Nyala $\left(R^{2}=1\right), \operatorname{SB} 19\left(R^{2}=\right.$ $1)$, and SB20 $\left(\mathrm{R}^{2}=1\right)$.
\end{abstract}

Key Words: Crop coefficient, evaporation, Glycine max, shoot, soybean, transpiration

\section{RÉSUMÉ}

La détermination du besoin en eau de la plante dans des milieux à ressources limitées est un défi, encore aggravé par l'hypothèse commune qui stipule que toutes les variétés d'une espèce ont les mêmes besoins en eau. L'objectif de cette étude était de déterminer indirectement l'évapotranspiration de la culture des variétés de soja, en utilisant l'évapotranspiration de référence et la teneur en eau de la pousse sous labour et sans labour. Les traitements étaient sans labour et avec labour conventionnel comme parcelles principales, et les variétés de soja Nyala, SB19, et SB20 comme sous parcelles, répliquées trois fois. L'évapotranspiration des cultures (ET $)$ et le coefficient de culture $\left(\mathrm{K}_{c}\right)$ étaient différents entre les variétés, et augmentaient durant la période de croissance. SB20 avait la valeur la plus élevée de $\mathrm{K}_{\mathrm{c}}(0,8437$ à 87 jours après plantation - DAP) ; suivie de SB19 $(0,7888$ à 70 DAP), et Nyala (0,7026 à 66 DAP). Inversement, l'efficience d'utilisation de l'eau (WUE) était 0,58 dans SB19, 0,52 dans Nyala, et 0,47 dans SB20. La validation de l'ET ${ }_{c}$ calculée en utilisant la fonction de production de la culture a montré une corrélation $\mathrm{r}=0.97$ entre les rendements observés et prédits des trois variétés. De plus, la racine des carrées moyens normalisés de l'erreur (NRMSE) et l'index d'accord (d) étaient 0,14 et 087, 
respectivement indiquant une concordance précise. La valeur calculée du coefficient de culture était fortement corrélée avec la valeur observée de la teneur en eau de la pousse de Nyala $\left(R^{2}=1\right), \operatorname{SB} 19\left(R^{2}=1\right)$, et $\mathrm{SB} 20\left(\mathrm{R}^{2}=\right.$ 1).

Mots Clés : Coefficient de culture, évapotranspiration, Glycine max, pousse, soja, transpiration

\section{INTRODUCTION}

Crop coefficient is an important determinant of crop evapotranspiration (Allen et al., 1998; Pereira et al., 2015); yet, crop evapotranspiration is fundamental in irrigation schedules under atmospheric conditions. Additionally, the amount and distribution of rainfall received in a region influences the irrigation scheduling. This is because the amount of rainfall influences soil water content. In situations where soil-based irrigation scheduling methods (Soulis et al., 2015; Valdés et al., 2015) are used, direct soil water measurement affects irrigation amount, while in the atmospheric-based methods, the soil water content affects evapotranspiration. Most regions in Sub-Saharan Africa are dependant on rainfall for successful crop production (Foeken, 1994; Herrero et al., 2010). However, these regions are increasingly experiencing erratic rainfall amounts and distribution (Kisaka et al., 2015; Ngetich et al., 2014; Thornton, 2010). This has led to mid-season drought (Kisaka et al., 2015; Ngetich et al., 2014), and thus the need to understand and manage water requirement of crops through evapotranspiration.

Soybean (Glycine max L. Merril), a crop whose production is being promoted in SubSaharan Africa (Chianu et al., 2009) is adversely affected by mid-season drought. This is due to the continuous erratic rainfall distribution and amount which mostly occur at the important stages of soybean growth; flowering, pod filling and seed filling stages (Mahasi et al., 2011; Daryanto et al., 2015; Omondi et al., 2015). Cover cropping, conservation tillage and mulching are some soil water management techniques (Wakindiki et al., 2007; Itabari et al., 2011) practised during mid-season drought. Moreover, the major strategy is sowing of drought tolerant and early maturing varieties of soybean (Mahasi et al., 2011). These varieties have different crop coefficients (Pereira et al., 2015), although, determination of crop coefficient for individual varieties is yet to be conducted, owing to the sensitivity, accuracy and, huge equipment investment required for such experiments (Irmak et al., 2013; Majidi et al., 2015; RuizPeñalver et al., 2015). Therefore, more efficient, effective, but also low-cost procedures for determining crop coefficient of these varieties is required. This could be achieved by borrowing the ideas behind irrigation scheduling methodologies as they input the amount of water required by a plant.

Methods used in irrigation scheduling are evolving from atmospheric-based (Lamm and Rogers, 2015), to soil-based (Soulis et al., 2015; Valdés et al., 2015), and now plantbased (De la Rosa et al., 2015; Shi et al., 2015). However, it could be a combination of soil and atmospheric conditions (Paraskevopoulos and Singels, 2014) or the three methods involving soil-plant-atmosphere continuum. Plant based methods, if well monitored, have been commended as the best option (Fernández, 2014) as they measure the 'patient'. Such methods as daily maximum stem diameter shrinkage (De la Rosa et al., 2015), leaf water potential (Unlu et al., 2014), stem water potential (Gonzalez-Dugo et al., 2014) and sap flow (Hechmi et al., 2014; Zuniga and Poblete-echeverría, 2014) can measure the water status of the plant (Fernández, 2014). It has been shown that stem water potential, leaf water potential, and sap flow could be used to determine the amount of water applied through irrigation to a plant. This, therefore, implies that a 
methodology which measures water content of both stems and leaves (shoot water content) could be more precise than either through destructive sampling of the shoot in the determination of the water requirement of the plant is involved. From the crop evapotranspiration $\left(\mathrm{ET}_{\mathrm{C}}\right)$ calculation (Pereira et al., 2015), the only difference in amount of irrigation water applied to species grown in the same agro-ecological zone, influenced by similar atmospheric conditions and soils is crop coefficient. Considering this, reference evapotranspiration is calculated using Penmann-Monteith equation and finally calculation of crop evapotranspiration. The objective of this study was to establish crop coefficients and evapotranspiration of different soybean varieties using shoot water content and reference evapotranspiration $\left(\mathrm{ET}_{0}\right)$.

\section{MATERIALS AND METHODS}

Reference evapotranspiration. Reference evapotranspiration was calculated using the Penmann-Moteith Equation (Allen et al., 1998):

$$
\mathrm{ET}_{0}=\frac{0.408 \Delta \underline{\Delta\left(\mathrm{R}_{\mathrm{n}}-\mathrm{G}\right)+900 /(\mathrm{T}+273)}}{\Delta+\gamma\left(1+0.34 \mathrm{U}_{2}\right)} \underline{\mathrm{U}}_{2}\left(\mathrm{e}_{\mathrm{s}}-\mathrm{e}_{\mathrm{a}}\right)
$$

Equation 1

Where:

$\mathrm{ET}_{\mathrm{o}}=$ reference evapotranspiration $[\mathrm{mm}$ day $\left.^{-1}\right], \mathrm{Rn}=$ net radiation at the crop surface [MJ $\mathrm{M}^{-2}$ day $\left.^{-1}\right], \mathrm{G}=$ soil heat flux density [MJ $\mathrm{m}^{-2}$ day $\left.^{-1}\right], \mathrm{T}=$ mean daily air temperature at 2 $\mathrm{m}$ height $\left[{ }^{\circ} \mathrm{C}\right], \mathrm{U}_{2}=$ wind speed at $2 \mathrm{~m}$ height $\left[\mathrm{ms}^{-1}\right], \mathrm{e}_{\mathrm{s}}=$ saturation vapour pressure $[\mathrm{kPa}]$, $\mathrm{e}_{\mathrm{a}=}$ actual vapour pressure $[\mathrm{kPa}], \mathrm{e}_{\mathrm{s}}-\mathrm{e}_{\mathrm{a}}=$ saturation vapour pressure deficit $[\mathrm{kPa}], "=$ slope vapour pressure curve $\left[\mathrm{kPa}{ }^{\circ} \mathrm{C}^{-1}\right]$, and ã $=$ psychrometric constant $\left[\mathrm{kPa}{ }^{\circ} \mathrm{C}^{-1}\right]$ usually about $0.067 \mathrm{kPa}^{\circ} \mathrm{C}^{-1}$.

$\mathrm{Rn}$ and $\mathrm{G}$ were calculated using Shuttleworth, (1992) equations; whileeffective depth of the roots for all the varieties was assumed as $1 \mathrm{~m}$.

$G=C_{S} d_{S} \frac{T_{2}+T_{1}}{\Delta t}$ Equation 2

Where:

$\mathrm{G}$ is soil heat flux $\left(\mathrm{MJm}^{-2} \mathrm{day}^{-1}\right), \mathrm{C}_{\mathrm{S}}$ is soil heat capacity $\left(\mathrm{MJm}^{-3 \circ} \mathrm{C}^{-1}\right), \mathrm{d}_{\mathrm{s}}=$ effective soil depth (m), $\mathrm{T}_{2}$ is air temperature at the end of the period considered $\left({ }^{\circ} \mathrm{C}\right), \mathrm{T}_{1}$ is air temperature at the beginning of the period considered $\left({ }^{\circ} \mathrm{C}\right)$, and " $t$ is length of time interval (days).

$$
\begin{aligned}
& R_{n}=(1-\alpha)\left(0.25+0.5 \frac{n}{N}\right) S_{0}- \\
& \left(0.9 \frac{n}{N}+0.1\right)(0.34-0.14 \sqrt{E d}) \sigma T^{4}
\end{aligned}
$$

Equation 3

Where:

$\mathrm{n}$ is the bright sunshine hours per day (h), $\mathrm{N}$ $=$ the total day length $(\mathrm{h}), \mathrm{S}_{0}=$ the extraterrestrial radiation $\left(\mathrm{MJm}^{-2}\right.$ day $\left.^{-1}\right), \mathrm{Ed}=$ the vapor pressure $(\mathrm{kPa}), \sigma=$ the StefanBoltzmann constant $\left(4.903 \times 10^{-9} \mathrm{MJm}^{-2} \mathrm{~K}^{-4}\right.$ day $\left.^{-1}\right), \mathrm{T}=$ the air temperature $(\mathrm{K})$, and $\alpha=$ the reflection coefficient.

$e_{s}=0.6108 \exp \left[\frac{17.27 T}{T+237.3}\right] \ldots .$. Equation 4

Where:

$\mathrm{e}_{\mathrm{s}}$ saturation vapour pressure $[\mathrm{kPa}]$, and $\mathrm{T}$ the air temperature $\left({ }^{\circ} \mathrm{C}\right)$.

$e_{a}=e_{s} \frac{R H}{100}$ Equation 5

Where:

$\mathrm{e}_{\mathrm{a}}$ is the actual vapour pressure $(\mathrm{kPa}), \mathrm{e}_{\mathrm{s}}$ is the saturation vapour pressure $(\mathrm{kPa}), \mathrm{RH}$ is relative humidity (\%). 


$$
\Delta=\frac{4098\left[0.6108 \exp \left(\frac{17.27 T}{T+237.3}\right)\right]}{(T+237.3)^{2}}
$$

Equation 6

Where:

$\Delta$ is the slope of saturation vapour pressure curve at air temperature $\mathrm{T}\left(\mathrm{kPa}^{\circ} \mathrm{C}^{-1}\right)$, $\mathrm{T}$ is air temperature $\left({ }^{\circ} \mathrm{C}\right)$.

Crop coefficient. Shoot water content was assumed to be crop coefficient, as crop evapotranspiration is always determined under unlimited water supply (Pereira et al., 2015), and hence the shoot water content reflects the soil water content and the ability of absorption by a variety. Additionally, crop evapotranspiration is important in irrigation scheduling and so is the shoot water content (Fernández, 2014). The shoot water content was measured five times during the crop growth period. According to FAO PenmanMonteith (Allen et al., 1998), $\mathrm{K}_{\mathrm{C}}$ is:

$$
\begin{aligned}
& K_{C}=\frac{E T_{C}}{E T_{0}} \\
& E T_{C}=K_{C} \times E T_{0}
\end{aligned}
$$

Assuming $\mathrm{K}_{\mathrm{C}}$ to be equivalent to shoot water content over a given period, then:

$E T_{C}=$ shoot water content $X E T_{0}$

Equation 9

Model validation using Crop Production function. Jensen (1968), reported a crop production function of:

$W U E=\frac{Y}{E T}$ Equation 10

From this function, $\mathrm{Y}$ is yield and ET is actual evapotranspiration/crop evapotranspiration.
$W U E=\frac{Y}{\text { shoot biomass }} \ldots \ldots \ldots . .$. Equation 11

Using Equation 11, predicted yield was calculated. To evaluate the model proposed for calculation of ETc from dry shoot biomass, the observed and predicted yield were analysed for best fit using the normalised root mean square error (NRMSE) and index of agreement (d) where NRMSE closer to 0 and d near 1 signify best fit (Shabani et al., 2015). After proving that, ETc was calculated using dry shoot biomass, $\mathrm{Kc}$ is calculated usingEquation 8knowing that $\mathrm{ET}_{0}$ is calculated from Equation 1 using the weather data.

Site description and experimental procedure. The experiment was conducted in Rarieda district, Siaya County (0Ú $08^{\prime} \mathrm{N}$, 34Ú 23 E). This area lies in Agro-ecological Zone LM 4 (Lower midland cotton zone), receiving a mean annual rainfall of $1000 \mathrm{~mm}$ and mean temperature of $22^{\circ} \mathrm{C}$. The soils are well drained, very deep and dark red (classified as Orthicferalisols) (Jaetzoldet al., 2005).

The treatments were two tillage methods (conventional tillage and no tillage) tested with three soybean varieties (Nyala, SB19, and SB20). The conventional farmer tillage method was the control treatment compared with no tillage, which is a component of conservation cultivation that has minimum soil disturbance and conserves soil moisture (Franchini et al., 2012). During the long rains of March to August, 2011 (LR2011) and short rains season of September to December, 2011 (SR2011), the treatments were randomised in a split-plot arrangement and replicated thrice. Randomised complete block design was used. No tillage and conventional tillage methods were the main plots; while soybean varieties were sub-plots. Conventional tillage mimicked farmer's practice of hand-hoe tilling at $20 \mathrm{~cm}$ depth, before the onset of rains; and no tillage was done using non-selective herbicide. The herbicide sprayed at 1.5 litres in 100 litres of water contained glyphosate as active ingredient. 
The three soybean varieties were: Nyala, a local early maturing variety which nodulates with specific rhizobia and is susceptible to soybean rust. This variety was suitable for the study as it was popular among farmers in Western Kenya. The rest were two International Institute for Tropical Agriculture (IITA) bred varieties called, TGx 1740-2F and TGx1448-2E, but locally known in Kenya as SB19 and SB20, respectively. These two varieties are promiscuous, and SB19 is medium maturing; while SB20 is late maturing (Tefera, 2011). The two varieties were new introductions in Western Kenya, and hence testing their performance against a local variety was prudent to encourage adoption.

Phosphorus was blanketly applied at $30 \mathrm{~kg}$ $\mathrm{P} \mathrm{ha}^{-1}$ as Triple Super Phosphate (TSP); and potassium at $30 \mathrm{~kg} \mathrm{~K} \mathrm{ha}^{-1}$ as Muriate of Potash (MOP) in furrows of $5 \mathrm{~cm}$ depth by $5 \mathrm{~cm}$ away from planting rows before planting. Seeds were treated with BIOFIX inoculants containing rhizobium strain USDA 110, using the slurry method of Somasegaran and Hoben (1994) at $10 \mathrm{~g}$ of BIOFIX for every $1 \mathrm{~kg}$ of seeds. The inoculated seeds were sown immediately after inoculation to ensure maximum survival of introduced rhizobial cells. No tillage plots were weeded by hand pulling of weeds; whereas hoes were used in conventional tillage plots at interval of two weeks.

Data collection and analysis. Standard cores (diameter of $5 \mathrm{~cm}$ and height of $5 \mathrm{~cm}$ ) were used to collect soil samples at depths of 10 , 20 and $30 \mathrm{~cm}$,for soil water content measurement at $50 \%$ full bloom (R2), pod filling (R3) and seed filling (R5). These are the important stages of soybean growth in soil moisture studies (Doss et al., 1974). The samples consisted of soils taken from three positions randomly selected within a plot.Their fresh and dry weights were measured. Weights were measured after drying the samples in oven at $105^{\circ} \mathrm{C}$ for 48 hours. Soil moisture content was calculated using a gravimetric method (Hillel, 1980).
Biomass samples were collected at 21,36, 51, 66, and 81 (Nyala), 102 (SB19), 118 (SB20) days after planting (DAP). Plants were sampled randomly in an area of $0.1 \mathrm{~m}^{2}$ within the net plot. Roots were separated from shoots at the first node from the ground, using a kitchen knife. Fresh weights were measured and dry weights determined after oven drying at $65^{\circ} \mathrm{C}$ in constant weight for 48 hours.

At physiological maturity, plants within a net plot of $7.8 \mathrm{~m}^{2}$ were harvested. Fresh weight of pods sub-sampled was taken, before being threshed. Fresh weights of the seeds and husks were also recorded. The seeds were oven-dried at $65^{\circ} \mathrm{C}$ (model - Memmert UNB 500) for 72 hours and their dry weights taken.

Moisture content after drying was $12.5 \pm 0.5 \%$. The total dry yield was calculated by multiplying dry weights of sub-samples by total fresh weight then diving the result by fresh weight of sub-samples.

Climatic data obtained from meteorological station were used in computation of $\mathrm{ET}_{0}$. The climatic data were: radiation, daily maximum and minimum temperature, wind speed and direction, relative humidity, pan evaporation and rainfall amounts. Shoot biomass, shoot water content and yield data were analysed for ANOVA in SAS software version 9.2 (SAS, 2002). They were used to calculate water use efficiency (WUE). Soil moisture content data were also analysed in SAS and means separated using least significant difference (LSD).

\section{RESULTS}

Soil moisture content. Soil moisture content was not significantly different for tillage method and soybean variety interaction, neither was it significant for the interaction between tillage and soil depth. However, soil moisture content under interaction of soybean variety and soil depth was significant. Soil moisture content increased with depth under all varieties except for SB19 at full bloom (Table 1). At pod filling, soil moisture content under all the three varieties was not significant. At seed filling, there was significant difference between 
$10 \mathrm{~cm}$ depth and $20-30 \mathrm{~cm}$ depth. Soil moisture content at $10 \mathrm{~cm}$ depth was lowest under all varieties and increased with depth (Table 1). Soil moisture content under the varieties was significant except at pod filling stage. At full bloom, soil moisture content under SB19 was the highest followed by SB20, while at seed filling soil moisture was highest under Nyala (Table 2).

Crop evapotranspiration $\left(\right.$ ET $\left._{\mathrm{C}}\right)$. Regression of $\mathrm{ET}_{0}$ against ETc indicated the coefficient of determination $\left(\mathrm{R}^{2}\right)$ was better with growing days except for SB20 (Figs. 1-3). At 81 days after planting Nyala, the $\mathrm{ET}_{0}$ agreed with ETc (Fig. 1); while $98.45 \% \mathrm{ET}_{0}$ could predict ETc at 102 days (Fig. 2). As for SB20, only 19.2\% of $\mathrm{ET}_{0}$ could not predict ETc at 66 DAP (Fig. 3). Cropevapotranspiration $\left(\mathrm{ET}_{\mathrm{C}}\right)$ of all varieties increasedrapidly with growing time, plateaued towards physiological maturity and slightly declined (Fig. 4). The third order polynomial fitted all the three varieties,ETcof Nyala was the lowest and of SB20 was the highest (Fig. 4). Further, calculated crop coefficient strongly correlated with observed shoot water content of Nyala $(r=0.9998)$, SB19 $(r=0.9997)$, and SB20 $(r=0.9998)$ (Fig. 9).

TABLE 1. Soil moisture content under soybean varieties at full bloom, pod filling and seed filling at three soil depths

\begin{tabular}{|c|c|c|c|c|}
\hline \multirow[t]{2}{*}{ Variety } & \multirow[t]{2}{*}{ Depth $(\mathrm{cm})$} & \multicolumn{3}{|c|}{ Soil moisture $\left(\mathrm{mm} \mathrm{mm}^{-1}\right)$} \\
\hline & & Full bloom (R2) & Pod filling (R3) & Seed filling (R5) \\
\hline \multirow[t]{3}{*}{ Nyala } & 10 & $0.0855 \pm 0.0042 \mathrm{a}$ & $0.1803 \pm 0.0118 \mathrm{a}$ & $0.0724 \pm 0.0064 b$ \\
\hline & 20 & $0.0969 \pm 0.0040 \mathrm{a}$ & $0.1529 \pm 0.0091 \mathrm{a}$ & $0.0906 \pm 0.0058 \mathrm{a}$ \\
\hline & 30 & $0.1053 \pm 0.0046 \mathrm{a}$ & $0.1542 \pm 0.0097 \mathrm{a}$ & $0.1016 \pm 0.0055 \mathrm{a}$ \\
\hline \multirow[t]{3}{*}{ SB19 } & 10 & $0.2434 \pm 0.0031 \mathrm{a}$ & $0.1559 \pm 0.0133 \mathrm{a}$ & $0.0418 \pm 0.0036 b$ \\
\hline & 20 & $0.2161 \pm 0.0033 b$ & $0.1551 \pm 0.0125 \mathrm{a}$ & $0.0724 \pm 0.0047 \mathrm{a}$ \\
\hline & 30 & $0.2436 \pm 0.0044 a$ & $0.1696 \pm 0.0147 \mathrm{a}$ & $0.0740 \pm 0.0065 \mathrm{a}$ \\
\hline \multirow[t]{3}{*}{ SB20 } & 10 & $0.2220 \pm 0.0065 \mathrm{a}$ & $0.1707 \pm 0.0152 \mathrm{a}$ & $0.0481 \pm 0.0044 \mathrm{~b}$ \\
\hline & 20 & $0.2119 \pm 0.0052 \mathrm{a}$ & $0.1604 \pm 0.0098 \mathrm{a}$ & $0.0726 \pm 0.0032 \mathrm{a}$ \\
\hline & 30 & $0.2122 \pm 0.0041 \mathrm{a}$ & $0.1384 \pm 0.0111 \mathrm{a}$ & $0.0808 \pm 0.0071 \mathrm{a}$ \\
\hline
\end{tabular}

Means with different letters are significantly different at $\mathrm{P}<0.05$ within a variety for mean separation, $\pm \mathrm{SE}$ (standard error)

TABLE 2. Effect of soybean variety on soil moisture content at different stages of growth

\begin{tabular}{llll}
\hline Variety & \multicolumn{3}{c}{ Soil moisture $\left(\mathrm{mm} \mathrm{mm}^{-1}\right)$} \\
\cline { 2 - 4 } & Full bloom (R2) & Pod filling (R3) & Seed filling (R5) \\
\hline Nyala & $0.0959 \pm 0.0083 \mathrm{c}$ & $0.1625 \pm 0.0147 \mathrm{a}$ & $0.0881 \pm 0.0079 \mathrm{a}$ \\
SB19 & $0.2344 \pm 0.0091 \mathrm{a}$ & $0.1602 \pm 0.0154 \mathrm{a}$ & $0.0627 \pm 0.0058 \mathrm{~b}$ \\
SB20 & $0.2154 \pm 0.0096 \mathrm{~b}$ & $0.1565 \pm 0.0144 \mathrm{a}$ & $0.0672 \pm 0.0060 \mathrm{~b}$ \\
\hline
\end{tabular}

Means with different letters are significantly different at $\mathrm{P}<0.05$ within a columnfor mean separation, $\pm \mathrm{SE}$ (standard error) 

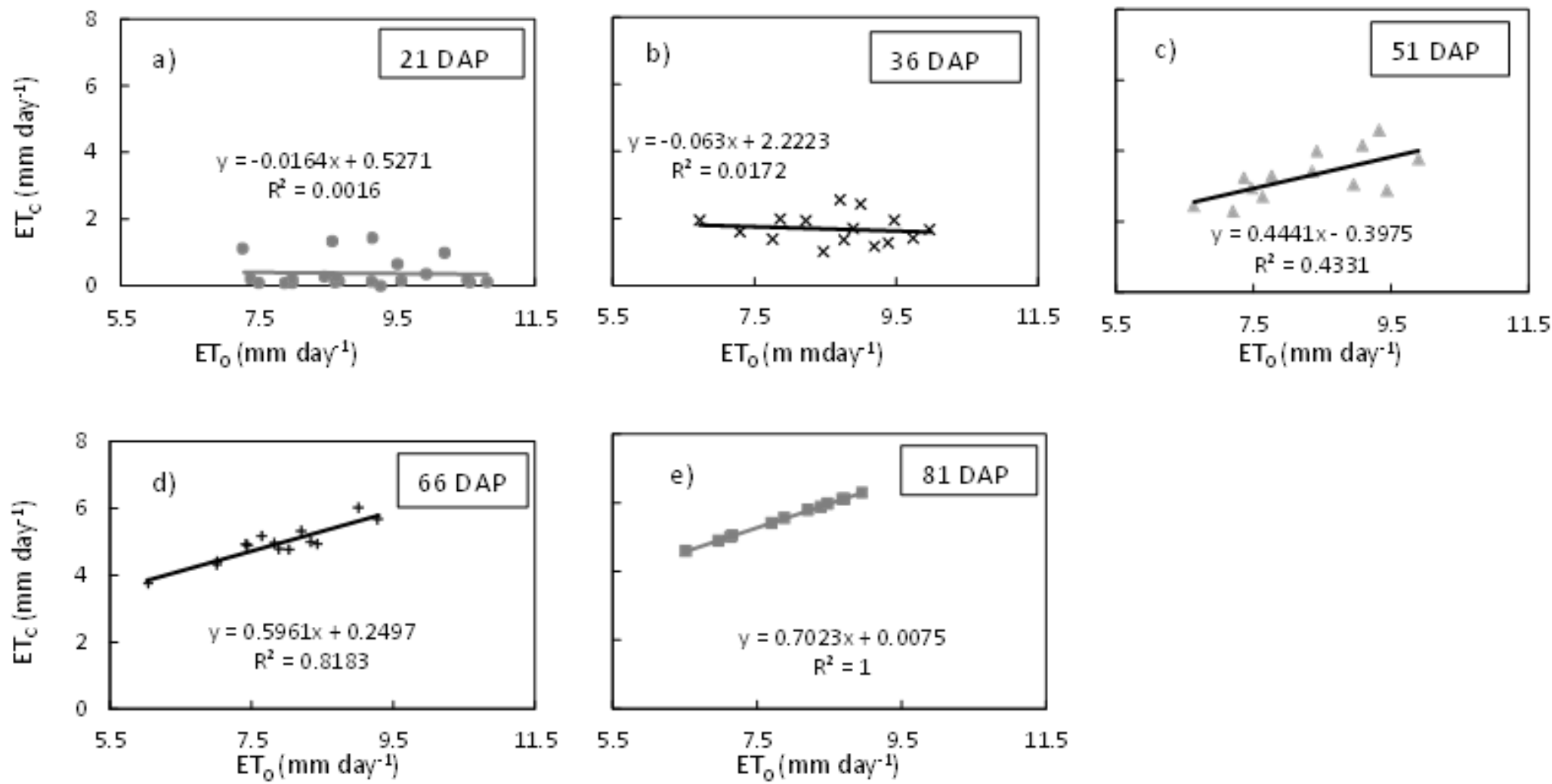

Figure 1. $\mathrm{ET}_{\mathrm{C}}$ of Nyala soybean variety against $\mathrm{ET}_{0}$ at different growth periods: a) 21, b) 36, c) 51, d) 66, and e) 81 DAP. DAP is days after planting at Rarieda District in Kenya. 

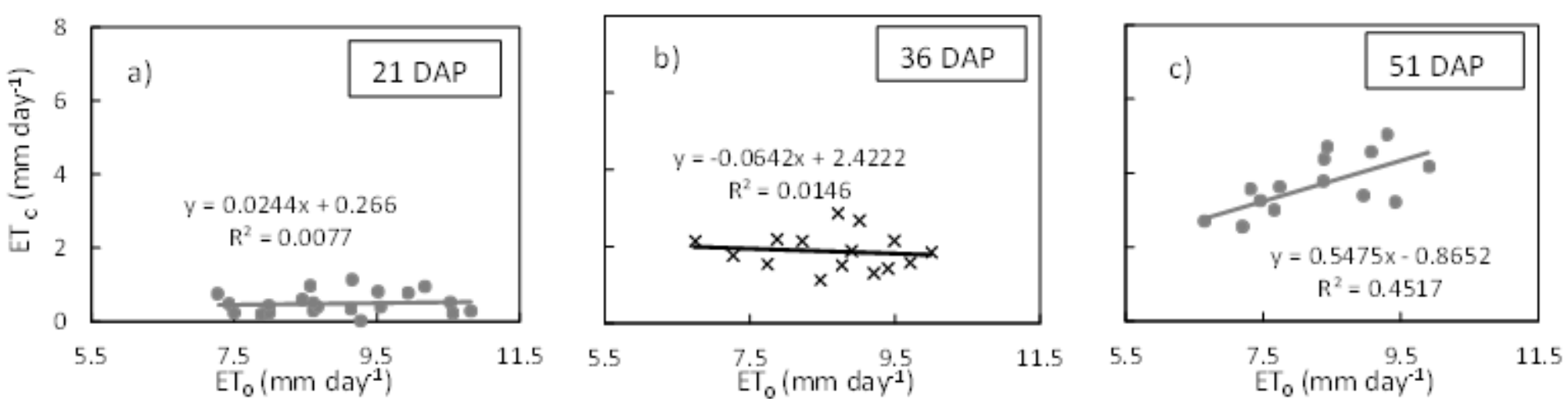

$\stackrel{W}{\infty}$
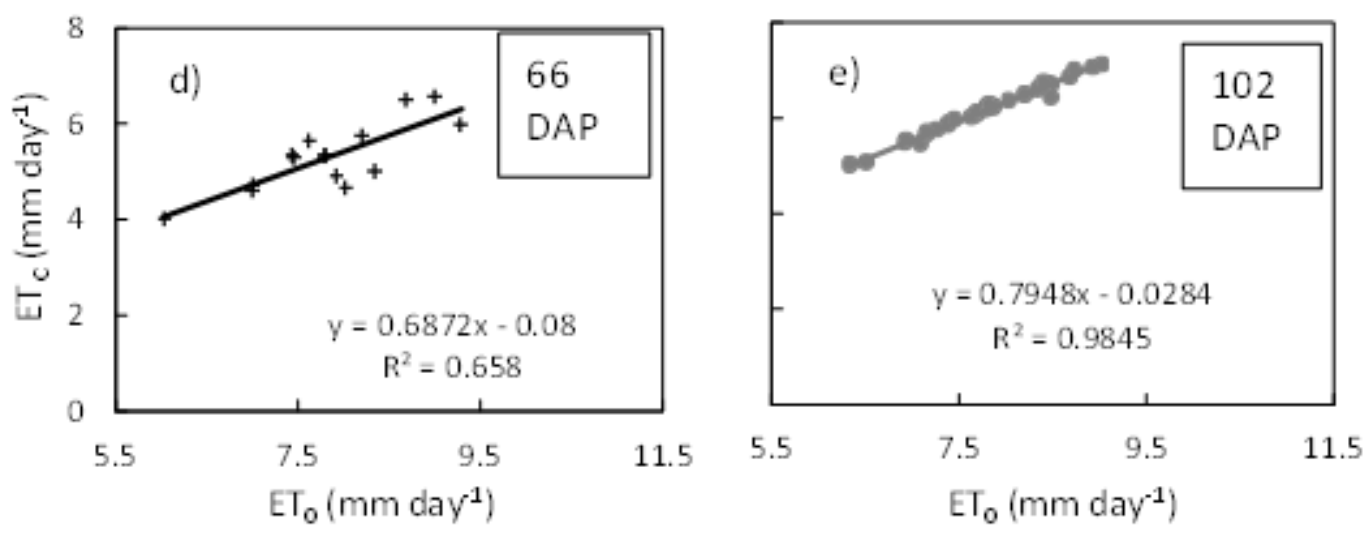

Figure 2. $\mathrm{ET}_{\mathrm{C}}$ of SB19 soybean variety against $\mathrm{ET}_{0}$ at different growth periods: a) 21, b) 36, c) 51, d) 66, and e) 102 DAP. DAP is days after planting at Rarieda District in Kenya. 

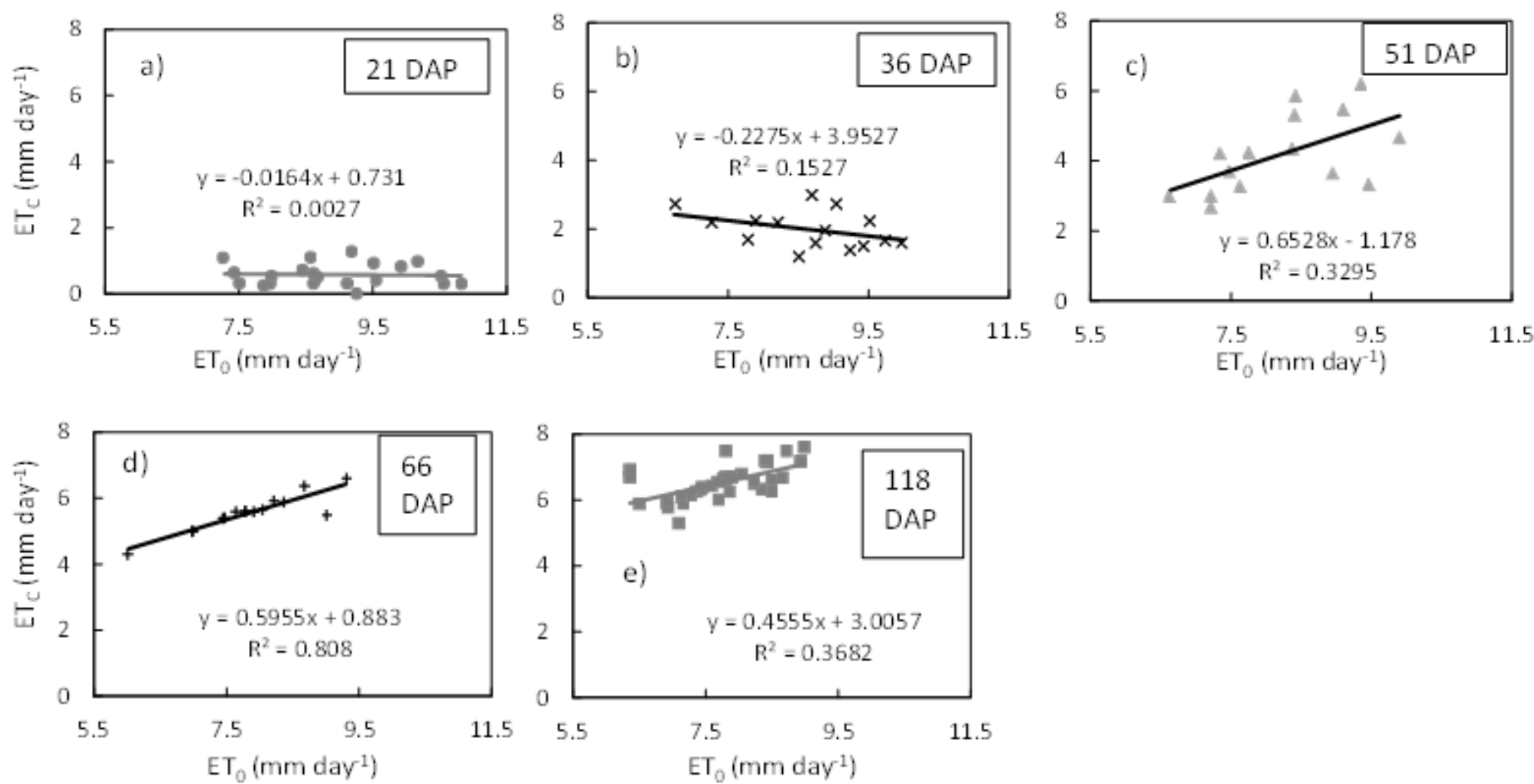

Figure 3. $\mathrm{ET}_{\mathrm{C}}$ of SB20 soybean variety compared to $\mathrm{ET}_{0}$ in the growing period: a) 21 , b) 36, c) 51, d) 66, and e) 118 DAP. DAP is days after planting at Rarieda District in Kenya. 

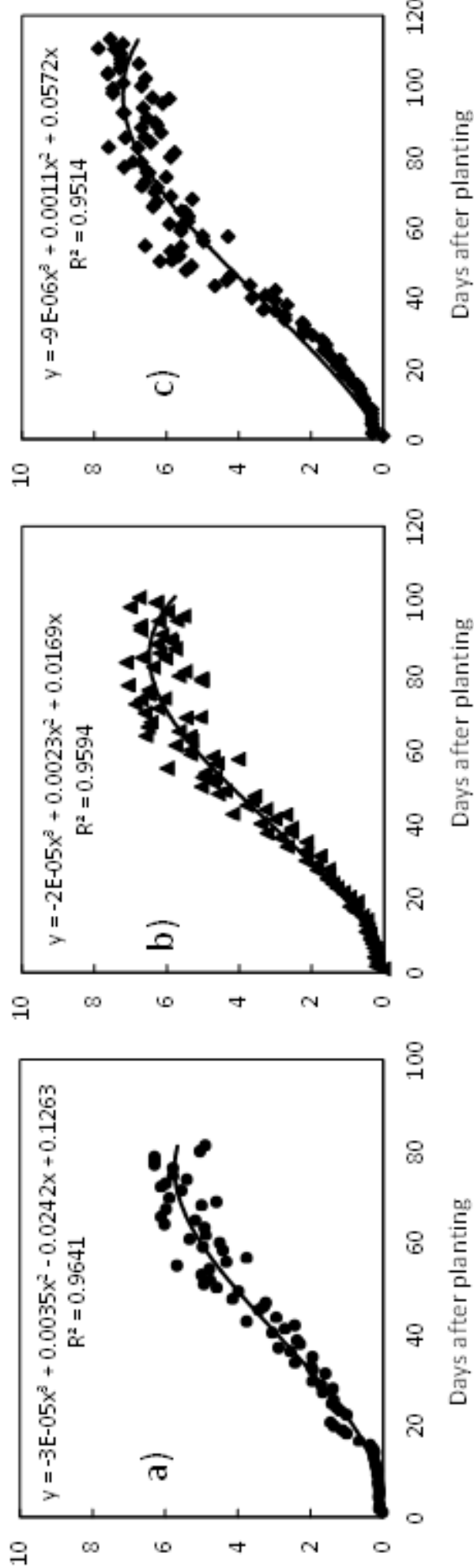

$\left({ }_{T}\right.$-Аep uш) $\supset \perp \exists$
From Equation 9:

$Y=W U E \times E T$ Equation 12

The results in Figures 5 and 6 show that:

$Y=m x$ Equation 13

Where:

$\mathrm{Y}$ is yield; $\mathrm{m}$ is slope, $\mathrm{x}$ is dry shoot mass (Fig. 5) or $\mathrm{ET}_{\mathrm{C}}$ (Fig. 6), there is an indication that $\mathrm{ET}_{\mathrm{C}}$ and dry shoot mass are related. Considering Fig. 5b and Fig. 6b of SB19:

$Y=0.5767 x$ Equation 14

for Figure 5b, where $\mathrm{x}=$ dry shoot mass $(\mathrm{kg}$ ha $^{-1}$ )

$Y=57.667 x$ Equation 15

for Figure 6b, where $\mathrm{x}=\mathrm{ET}_{\mathrm{C}}\left(\mathrm{mm}\right.$ day $\left.^{-1}\right)$

Both calculations show the same yield, it therefore means that:

0.5767 dry shoot mass $=57.667 E T_{C}$ Equation 16

dry shoot mass $=\mathrm{ET}_{\mathrm{C}}$ Equation 17

Thus

$\% E T_{C}=$ dry shoot mass Equation 18

Dry shoot mass and yield. The grain yields of each variety were accurately predicted by their dry shoot masses. A total of $52.3 \%$ of Nyala'sdry shoot mass produced grain yield, as $57.7 \%$ of SB19 dry shoot mass did the same; and $47 \%$ of SB20 dry shoot mass produced grain yield (Fig. 5). Similar results were obtained on correlating $\mathrm{ET}_{\mathrm{C}}$ with yield (Fig. 6). Validation of the measured yield of 

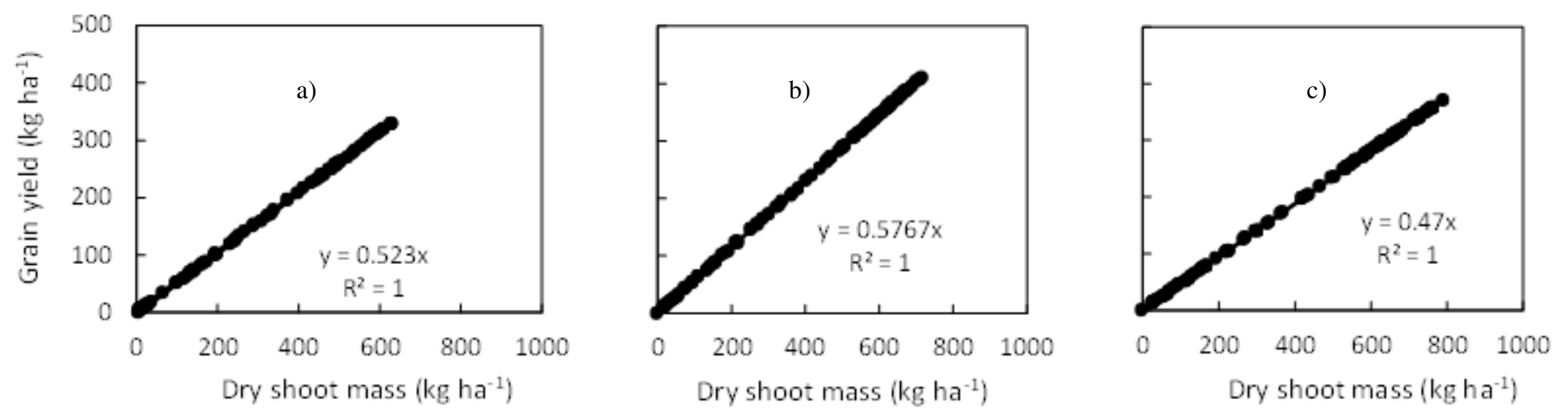

Figure 5. Relationship between grain yield and dry shoot mass of: a) Nyala, b) SB19, and c) SB20 soybean varieties at Rarieda District in Kenya.
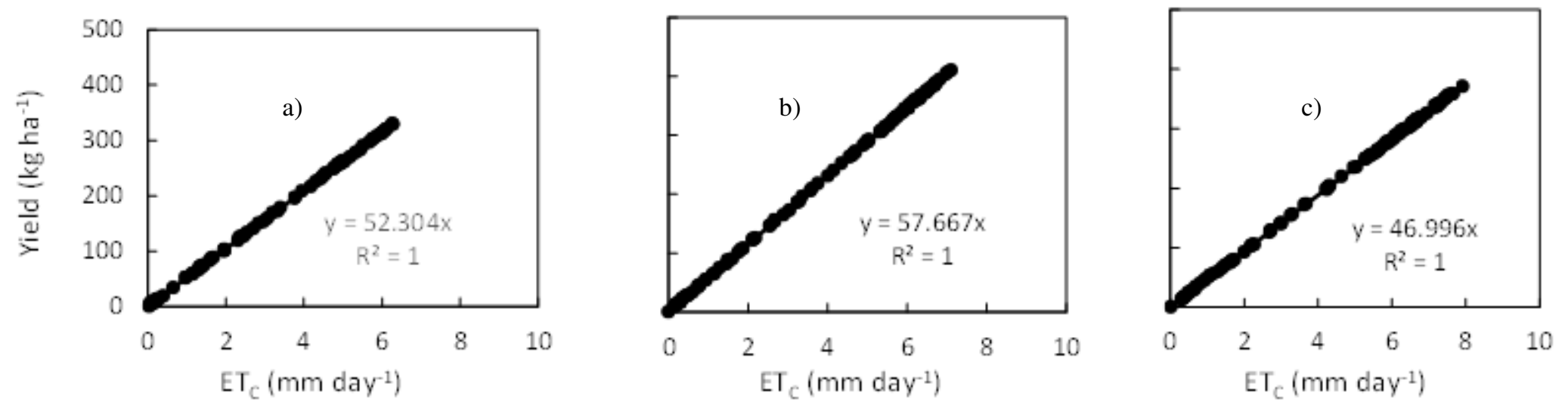

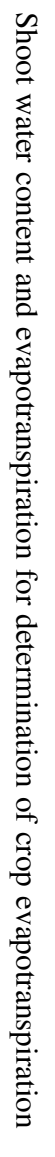

Figure 6. Relationship between grain yield and $\mathrm{ET}_{\mathrm{C}}$ of: (a) Nyala, (b) SB19, and (c) SB20 at Rarieda District in Kenya. 


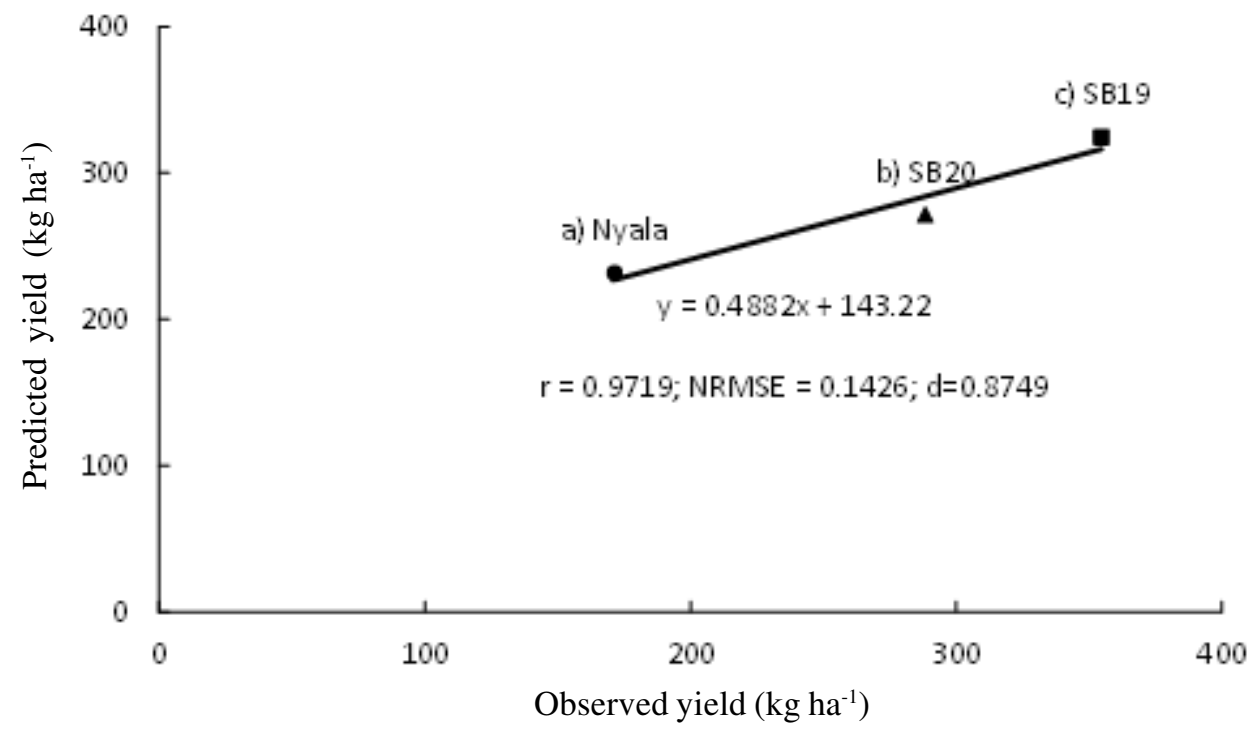

Figure 7. Comparison of the observed grain yield of: (a) Nyala, (b) SB20, and (c) SB19 soybean varieties with predicted.

Nyala, SB19, and SB20 against the calculated indicated a strong correlation of $r=0.9719$. Furthermore, the normalised root mean square error (NRMSE) and the index of agreement (d) were 0.1426 and 0.8749 , respectively; indicating the best fit (Fig. 7). After validation, crop coefficient $\left(\mathrm{K}_{\mathrm{C}}\right)$ was calculated, and the results showed increase in $\mathrm{K}_{\mathrm{C}}$ during the growth period(Fig. 8). However, the maximum $\mathrm{K}_{\mathrm{C}}$ for each variety was recorded at different days - Nyala was at 65 days, SB19 at 70 days and SB20 at 82 days after planting.

\section{DISCUSSION}

Soil moisture content. Soil moisture is important for successful crop production. However, soil moisture is highly critical in soybean at flowering and seed filling (Foroud et al., 1993; Karam et al., 2005). The $\mathrm{ET}_{\mathrm{C}}$ increase as soybean grew, followed by plateau at physiological maturity observed in the current experiment was due to increase in water requirement at the critical growth stages. Payero and Irmak (2013) also confirmed this trend. Further, a decline in soil moisture at seed filling of Nyala, SB19, and SB20 was indicative of increased water absorption at this stage. Withholding irrigation at flowering have been indicated to lead to $4 \%$ reduction in seed yield (Karam et al., 2005), while soil moisture decline at seed filling leads to 25\% (Foroud $e t$ al., 1993) or $28 \%$ (Karam et al., 2005) reduction.

Crop evapotranspiration. Crop evapotranspiration $\left(\mathrm{ET}_{\mathrm{C}}\right)$ is central to irrigation. It was different among the tested soybean varieties. These differences in ETc among varieties (Fig. 4) was majorly due to crop factors such as shoot and root growth. Wang and Liu (2007) reported that leaf area index (LAI) influences evaporation, actually, SB20 variety as an example in the current experiment had high shoot and root biomasses (Omondi et al., 2014) and hence high LAI which reduced evaporation. However, the gains in soil moisture content through canopy cover were negated by the absorption of more moisture to sustain this heavy vegetative growth and increased transpiration. This led to the overall decline in soil moisture under SB20 (Table 2). 

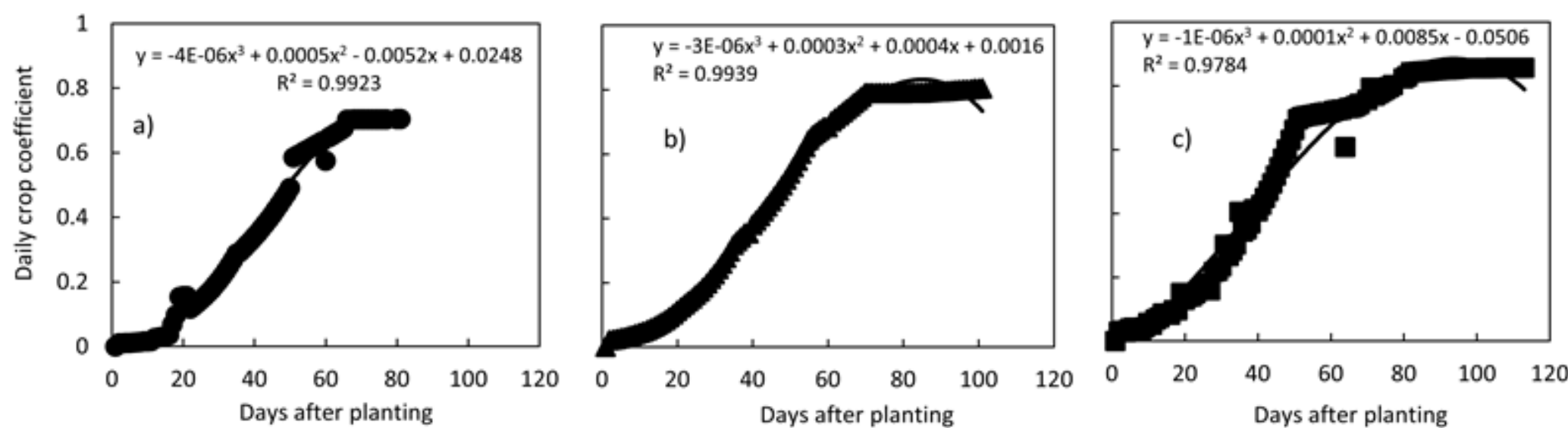

Figure 8. Distribution of crop coefficient of: (a) Nyala, (b) SB19, and (c) SB20 soybean varieties in the growing period.
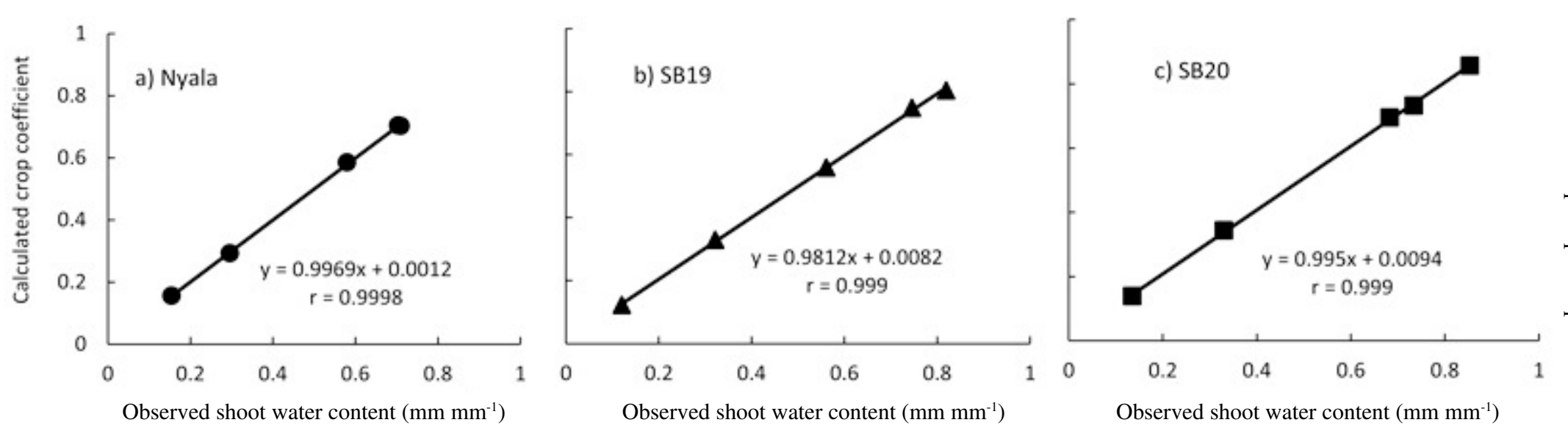

Figure 9. Correlation between shoot water content and calculated crop coefficient during growth of: (a) Nyala, (b) SB19, and (c) SB20 soybean varieties. 
Arnold et al. (2015) and Yan et al. (2014) also reported the influence of minimum canopy as the cause for increased evaporation. Evaporation as a factor of ETc had minimum fluctuation as it is dependent on solar radiation (Wang and Liu, 2007).

The days when the slope of the relationship between $\mathrm{ET}_{0}$ and $\mathrm{ET}_{\mathrm{C}}$ were negative (Fig. 1a,b, Fig. 2b, Fig. 3a, b) was perhaps due to high evaporation compared to transpiration (Sepaskhah and Ilampour, 1995; Villegas et al., 2015). Low transpiration was possible as the plants were young (21 and 36 days after planting) with less developed shoot biomass leading to low water requirement (Sepaskhah and Ilampour, 1995; Suku et al., 2014). As the plants grew water requirement increased (Suku et al., 2014) and transpiration and $\mathrm{ET}_{\mathrm{C}}$ too (Zhu et al., 2014; Villegas et al., 2015).

Crop coefficient. The crop evapotranspiration calculated predicted yield of Nyala, SB19 and SB20 (Fig. 6). This eases calculation of Kc without conducting complex soil water balance experiments, as these experiments usually require sensitive and sophisticated equipment (Irmak et al., 2013; Majidi et al., 2015; Ruiz-Peñalver et al., 2015) which are not readily available to resourcelimited farmers. In the current experiment, calculated $\mathrm{K}_{\mathrm{C}}$ increased with growth period and canopy expansion (Figs. 8 and 9). This increase in $\mathrm{K}_{\mathrm{C}}$ as growth period and shoot biomass was also observed by Lopez-Urrea $e t$ al. (2013). As the shoot expands, transpiration is increased this influences crop evapotranspiration and $\mathrm{K}_{\mathrm{C}}$. The calculated maximum Kc was 0.70 for Nyala, 0.80 for SB19 and 0.86 for SB20, while the value previously reported was 0.81 at mature pods (Karam et al., 2005). This proves that $\mathrm{K}_{\mathrm{C}}$ of the varieties are different within the same species, thus the need to always calculate it. Moreover, it has been shown that crop factors such as crop type, variety and stage of development influence evapotranspiration (Allen et al., 1998). Since the $K_{C}$ is different among various varieties, the simple equation developed in the current study is convenient for irrigation water calculations in the areas experiencing midseason drought. The successful application of the \%ETc = dry shoot mass equation in soybean could extend to other crops, once it is validated with field experiments. The calculation of the Kc through this equation, coupled with weather data to calculate $\mathrm{ET}_{0}$ facilitates ETc calculation leading to precise irrigation. This optimises the production system, saving water, fertiliser if fertigation method is applied and reduces leaching leading to yield increase per drop of water.

\section{CONCLUSION}

Calculating $\mathrm{K}_{\mathrm{C}}$ of varieties using biomass data enables its calculation in other agroecological zones where it is difficult to obtain $\mathrm{K}_{\mathrm{C}}$ due to lack of sophisticated equipment required. Knowing $\mathrm{K}_{\mathrm{C}}$ of each variety enhance precise irrigation and water management of crops.

\section{ACKNOWLEDGEMENT}

The authors' gratitude goes to N2-Africa project implemented then under CIAT, its staff based at MasenoStation-Kenya, and Egerton University-Kenyafor the funding and allocation of research facilities.

\section{REFERENCES}

Allen, R.G., Pereira, L.S., Raes, D. and Smith, M. 1998. Crop evapotranspiration: Guidelines for computing crop requirements. Irrigation Drainage Paper No. 56, FAO 300.

Arnold, S., Schneider, A., Doley, D. and Baumgartl, T., 2015. The limited impact of vegetation on the water balance of mine waste cover systems in semi-arid Australia. Ecohydrology 8:355-367.

Chianu, J.N., Ohiokpehai, O., Vanlauwe, B., Adesina, De Groote, H. and Sanginga, N., 2009. Promoting a versatile but yet minor 
crop: Soybean in the farming systems of Kenya. Journal of Sustainable Development in Africa 10:324-344.

Daryanto, S., Wang, L. and Jacinthe, P.A. 2015. Global synthesis of drought effects on food legume Production. PLoS One 10:e0127401.

De la Rosa, J.M., Domingo, R., GómezMontiel, J. and Perez-Pastor, A., 2015. Implementing deficit irrigation scheduling through plant water stress indicators in early nectarine trees. Agricultural Water Management 152:207-216.

Doss, B.D., Pearson, R.W. and Rogers, H.T., 1974. Effect of soil water stress at various growth stages on soybean yield. Agronomy Journal 66:297-299.

Fernandez, J.E. 2014. Plant-based sensing to monitor water stress: Applicability to commercial orchards. Agricultural Water Management 142:99-109.

Foeken, D. 1994. Climatic seasonality in Kenya: With special reference to coast province. East. South. African Geography Journal 5:28-43.

Foroud, N., Miindel, H., Saindon, G. and Entz, T. 1993. Irrigation science effect of level and timing of moisture stress on soybean plant development and yield components. Irrigation Science 13:149-155.

Franchini, J.C., Debiasi, H., Balbinot Junior, A.A., Tonon, B.C., Farias, J.R.B., Oliveira, M.C.N. and de, Torres, E. 2012. Evolution of crop yields in different tillage and cropping systems over two decades in southern Brazil. Field Crop Research 137:178-185.

Gonzalez-Dugo, V., Zarco-Tejada, P.J. and Fereres, E. 2014. Applicability and limitations of using the crop water stress index as an indicator of water deficits in citrus orchards. Agricultural and Forest Meteoroogy 198-199, 94-104.

Hechmi, C., Baligh, M., Afef, H., Zoubeir, M., Mohamed, B. and Dalenda, B. 2014. Effects of two drip-irrigation regimes on sap flow, water potential and leaf photosynthetic activity of mature olive trees. African Journal of Agricultural Research 9:24432452.

Herrero, M., Ringler, C., Steeg, J. Van De, Thornton, P., Zhu, T., Omolo, A., Koo, J. and Notenbaert, A. 2010. Climate variability and climate change/ : Impacts on Kenyan Agriculture, Food Policy. ILRI, Nairobi, Kenya.

Hillel, D. 1980. Fundamentals of soil physics, $1^{\text {st }}$ Ed. Academic Press, Massachusetts, USA.

Irmak, S., Odhiambo, L.O., Specht, J.E. and Djaman, K. 2013. Hourly and daily single and basal evapotranspiration crop coefficients as a function of growing degree days, days after emergence, leaf area index, fractional green canopy cover, and plant phenology for soybean. Transactions of the ASABE 56:1785-1803.

Itabari, J.K., Kwena, K., Esilaba, A.O., Kathuku, A.N., Muhammad, L., Mangale, N. and Kathuli, P. 2011. Land and water management research and development in arid and semi-arid lands of Kenya. In: Bationo, A., Waswa, B., Okeyo, J.M., Maina, F., Kihara, J.M. (Eds.), Innovations as key to the green revolution in Africa: Exploring the scientific facts. Springer Science and Business Media. pp. 427-437. Jaetzold, R. and Schimidt, H. 2005. Farm Management Handbook of Kenya (Rift Valley) $\left(2^{\text {nd }}\right.$ edn $)$. Ministry of Agriculture and Marketing, Nairobi, Kenya.

Jensen, M. 1968. Water consumption by agricultural plants. In: Kozlowski, T.T. (Ed.), Water Deficits and Plant Growth. Academic Press, New York, USA. pp. 121.

Karam, F., Masaad, R., Sfeir, T., Mounzer, O. and Rouphael, Y. 2005. Evapotranspiration and seed yield of field grown soybean under deficit irrigation conditions. Agricultural Water Management 75:226-244.

Kisaka, M.O., Ngetich, F.K., Mugwe, J.N., Mugendi, D. and Mairura, F. 2015. Rainfall variability, drought characterization, and 
efficacy of rainfall data reconstruction/ : Case of Eastern Kenya. Advances in Meteorology pp. 1-17.

Lamm, F.R. and Rogers, D.H. 2015. The importance of irrigation scheduling for marginal capacity systems growing corn. Applied Engineering in Agriculture 31:261-265.

Lehnert, M. 2014. Factors affecting soil temperature as limits of spatial interpretation and simulation of soil temperature. Acta Universitatis Palackianae Olomucensis - Geography, 45:5-21.

Lopez-Urrea, R., Montoro, A. and Trout, T.J. 2013. Consumptive water use and crop coefficients of irrigated sunflower. Irrigation Science 32:99-109.

Mahasi, J.M., Mukalama, J., Mursoy, R.C., Mbehero, P. and Vanlauwe, B. 2011. A sustainable approach to increased soybean production in western Kenya. In: African Crop Science Conference Proceedings 10: 115-120.

Majidi, M., Alizadeh, A., Farid, A. and Vazifedoust, M. 2015. Estimating evaporation from Lakes and Reservoirs under limited data condition in a semi-arid region. Water Resource Managament 29:3711-3733.

Ngetich, K.F., Mucheru-Muna, M., Mugwe, J.N., Shisanya, C. A., Diels, J. and Mugendi, D.N. 2014. Length of growing season, rainfall temporal distribution, onset and cessation dates in the Kenyan highlands. Agricultural and Forest Meteorology 188:24-32.

Omondi, J.O., Mungai, N.W., Ouma, J.P. and Baijukya, F.P. 2015. Mitigating mid-season drought effect in soybean (Glycine max $\mathrm{L}$. Merril ) in Western Kenya. Legume Research 38: 476-482.

Omondi, J.O., Mungai, N.W., Ouma, J.P. and Baijukya, P.F. 2014. Effect of tillage on biological nitrogen fixation and yield of soybean (Glycine max L . Merril) varieties.
Australian Journal of Crop Science 8:11401146.

Paraskevopoulos, A. L. and Singels, A., 2014. Integrating soil water monitoring technology and weather based crop modelling to provide improved decision support for sugarcane irrigation management. Computers and Electronics in Agriculture 105:44-53.

Payero, J.O. and Irmak, S. 2013. Daily energy fluxes, evapotranspiration and crop coefficient of soybean. Agricultural Water Management 129:31-43.

Pereira, L.S., Allen, R.G., Smith, M. and Raes, D. 2015. Crop evapotranspiration estimation with FAO56: Past and future. Agricultural Water Management 147:4-20.

Ruiz-Penalver, L., Vera-Repullo, J. A., JimenezBuendia, M., Guzman, I. and MolinaMartínez, J.M. 2015. Development of an innovative low cost weighing lysimeter for potted plants: Application in lysimetric stations. Agricultural Water Management 151:103-113.

SAS, I.I., 2002. SAS/STAT. SAS/STAT 9.2 Cary, NC, USA.

Sepaskhah, A.R. and Ilampour, S. 1995. Effects of soil moisture stress on evapotranspiration partitioning. Agricultural Water Management 28:311323.

Shabani, A., Sepaskhah, A.R. and KamgarHaghighi, A.A. 2015. A model to predict the dry matter and yield of rapeseed under salinity and deficit irrigation. Archives of Agronomy and Soil Science 61:525-542.

Shi, J., Li, S., Zuo, Q. and Ben-Gal, A. 2015. An index for plant water deficit based on root-weighted soil water content. Journal of Hydrology 522:285-294.

Shuttleworth, W.J. 1992. Evaporation. In: Maidment, D.R. (Ed.), Handbook of Hydrology. McGraw-Hill Inc, New York, Chapter 4.

Somasegaran, P. and Hoben, H.J. 1994. Handbook for Rhizobia Methods in 
Legume-Rhizobium Technology, $1^{\text {st }}$ Ed. Springer-Verlag, New York, USA. 231pp.

Soulis, K.X., Elmaloglou, S. and Dercas, N. 2015. Investigating the effects of soil moisture sensors positioning and accuracy on soil moisture based drip irrigation scheduling systems. Agricultural Water Management 148:258-268.

Suku, S., Knipfer, T. and Fricke, W. 2014. Do root hydraulic properties change during the early vegetative stage of plant development in barley (Hordeum vulgare)? Annals of Botany 113:385-402.

Tefera, H. 2011. Breeding for promiscuous soybeans at IITA. In: Sudaric, A. (Ed.), Soybean - Molecular aspects of breeding. Intech, Rijeka, Croatia. pp. 147-162.

Thornton, N. 2010. Climate change in Kenya: Focus on children, UNICEF, 30a Great Sutton Street, London, UK.

Unlu, M., Kanber, R., Koc, D.L., Ozekici, B., Kekec, U., Yesiloglu, T., Ortas, I., Unlu, F., Kapur, B., Tekin, S., Kathner, J., Gebbers, R., Zude, M., Peeters, A. and BenGal, A. 2014. Irrigation scheduling of grapefruit trees in a Mediterranean environment throughout evaluation of plant water status and evapotranspiration. Turkish Journal of Agriculture and Forest 38:908-915.

Valdés, R., Ochoa, J., Franco, J. A., SanchezBlanco, M.J. and Banon, S. 2015. Saline irrigation scheduling for potted geranium based on soil electrical conductivity and moisture sensors. Agricultural Water Management 149:123-130.

Villegas, J.C., Dominguez, F., Barron-Gafford, G. A., Adams, H.D., Guardiola-Claramonte,
M., Sommer, E.D., Selvey, A.W., Espeleta, J.F., Zou, C.B., Breshears, D.D. and Huxman, T.E. 2015. Sensitivity of regional evapotranspiration partitioning to variation in woody plant cover: insights from experimental dryland tree mosaics. Global Ecology and Biogeography 24:1040-1048. Wakindiki, I.I.C., Mochoge, B.O. and Ben-hur, M. 2007. Assessment of indigenous soil and water conservation technology for smallholder farms in semi-arid areas in Africa and close spaced trash lines effect on erosion and crop yield. In: Bationo, A., Waswa, B., Kihara, J. and Kimetu, J. (Eds.), Advances in integrated soil fertility management in Sub-Saharan Africa: Challenges and opportunities. Springer Netherlands. pp. 805-814.

Wang, H.X. and Liu, C.M. 2007. Soil evaporation and its affecting factors under crop canopy. Communication of Soil Science and Plant Analysis 38:259-271.

Yan, H., Zhang, C., Oue, H., Wang, G. and He, B., 2014. Study of evapotranspiration and evaporation beneath the canopy in a buckwheat field. Theoretical and Applied Climatology 122:721-728.

Zhu, J., Sun, D., Young, M.H., Caldwell, T.G. and Pan, F. 2014. Shrub spatial organization and partitioning of evaporation and transpiration in arid environments. Ecohydrology 8:1218-1228.

Zuniga, M. and Poblete-echeverria, C. 2014. Use of sap flow sensors to determine transpiration of a young drip- irrigated olive orchard ('Arbequina') under semi-arid conditions. Acta Horticulturae 1057:405410 . 